\title{
The Management of International Trade Risks
}

\author{
by Donald R. Lessard*
}

\section{Introduction}

It is now painfully clear that the debt problem of less developed countries (LDCs) is not over. At best, LDCs and their creditors face a decade-long workout; at worst, LDCs, and to a lesser extent their creditors, face even more serious crises than those they have confronted to date. Under such a scenario it is tempting to take a defensive posture, limiting new exposures while seeking to salvage as much as possible from existing ones, but a positive tack would be more constructive.

There appears to be great potential for new financing initiatives that will improve the lot of LDCs and provide a attractive return to lenders, especially when the indirect benefits of greater trade with LDCs are taken into account. While this may sound like making water run uphill. it has a logical basis. The "magic" ingredient is to better exploit the comparative advantage of various parties in managing international risks.

Most current discussions of the LDCs debt problem indicate that the major issue in international risk management is the mitigation and avoidance by lenders of risks of nonperformance by LDCs. However, another equally important dimension is the appropriate allocation of risks faced by LDCs among various lenders and investors. To solve only the first problem is analogous to addressing moral hazard by eliminating all fire and casualty insurance.

When viewed in terms of comparative advantage, the management of international risks inherent in the current structure of financing for LDCs is woefully inadequate and there is much room for improvement.

This paper is organized in three parts. Part I outlines the sources of comparative advantage in international risk management as they apply to LDCs. Part II examines the current structure of external financing for LDCs in light of this comparative advantage, concluding with an identification of the general dimensions along which it could be improved. Part III concludes with a set of concrete suggestions that might be implemented by members of the Berne Union to realize their potential comparative advantage as lenders and insurers.

* Stanford University Graduate School of Business and M.I.T. Sloan School of Management. 


\section{Comparative advantage in the management of international risks}

Comparative advantage in managing risk can arise in any one of the components of that process. Five such components are defined in Table 1.

Table 1: Components of risk management ${ }^{1}$

Identification

Analysis of incidence

Mitigation

Transfer

Loss management
What could occur, how and why.

What effect could these events have on the commercial operation or contract in question.

How can the likelihood of these events or their adverse effects be minimized.

How should the risks which cannot be mitigated be allocated among parties by contract or insurance.

Given an occurence, how can the resulting losses be minimized after the fact.

Clearly, some parties will be better than others at identifying risks and assessing their impacts on particular contracts or undertakings. This depends in large part on a party's prior experience and scope of activities. To the extent that the risks in question entail a behavioral element, comparative advantage in mitigation will reflect various parties' leverage or bargaining power, which in turn reflects the direct or indirect sanctions it can bring to bear on the nonperforming party. Comparative advantage in terms of risk allocation, in contrast, will reflect the parties' appetite for risk and, more importantly, the diversity of its exposures and hence its ability to ameliorate risk through diversification. These sources of comparative advantage are summarized in Table 2.

Table 2: Sources of comparative advantage in international risk management

Identification

Analysis of incidence

Mitigation

Transfer

Loss management
Superior information: experience, scope, access.

Superior information: experience, scope, access.

Leverage: ability to monitor behavior and to impose sanctions, seniority, perception of legitimacy on part of debtor and other comparative creditors.

Diversification: degree of exposure to same or related risks.

Depends on nature of risk.

${ }^{1}$ Adapted from Radcliffe [1983]. 
In some cases, these functions are separable, and optimal risk management will involve specialization by function as well as by of risk. In other cases, though, one function may not be separable from another and comparative advantage will reflect some averaging of the various functions. Consider the case of commercial banks lending to LDCs. They have an advantage in risk mitigation relative to most other potential lenders because of their relatively high degree of bargaining power vis a vis LDCs, but a disadvantage in risk allocation given their relative overexposure to $\mathrm{LDC}$ credits.

\subsection{Application to international trade risks}

The concept of comparative advantage in risk management is a general one. However, the strength of this comparative advantage in terms of each of the risk management functions and the relative importance of the functions will depend on the type of risk being addressed.

Financial contracts across national boundaries - including the financing of trade and services - face a hierarchy of risks. ${ }^{2}$ All contracts, with the exception of those involving an escrowing of specified foreign exchange earnings, are exposed to transfer risk - the risk that the country will not have and make available the foreign exchange to service this debt. General obligations of the sovereign face only this risk (apart from the minimal risk that a country will repudiate its debts out of ideology or calculations of net worth). Obligations denominated in currencies other than those of the borrowing country, but payable in its jurisdiction, are also subject to the risk of exchange controls, as holders of Mex-dollar deposits and Mexican petro-bonds learned to their dismay. Debt contracts denominated in the local currency, of course, are also subject to the risk of reduced purchasing power through inflation and devaluation. In addition, equity investments or loans to specific companies or projects are subject to the commercial risks of the firm or project. International trade risks encompass virtually all levels in this hierarchy.

A critical aspect of most of these risks is that they are not pure risks, but involve both chance and choice. Put another way, they are the result not only of events outside of the country's control, but also of the actions of the country, often but not always in response to outside

\footnotetext{
${ }^{2}$ This hierarchy of risks has led to an often confusing set of definitions and explanations of risk depending on the perspective that is being taken. With regard to international bank lending, for example, the term country risk is applied to the risk of rescheduling or outright default resulting from external payments crises. These crises are viewed as stemming from bad luck, bad faith, mismangement or some mixture of the three (Eaton and Gersowitz [1982] and Walter [1982]). In the case of direct foreign investment, in contrast, political risk typically is defined as the risk of losses resulting from expropriation or domestic policy shifts. These acts, in turn, are often associated with political discontinuities (Kobrin [1982], Agmon and Dietrich [1980]. and Ghadar, Kobrin, and Moran [1983]). With portfolio investment, in contrast, country risk is defined as the common variability in the returns from holding shares of firms based in or operating in a given country (Agmon [1972]. Lessard [1976], or Solnik [1973]). Finally, with reference to international money markets, political risk is typically viewed as the risk of exchange controls (Aliber [1973, $1978]$ and Dooley and Isard [1980]). For attempts to place these various risks in a general framework, see Lessard, Eckaus, Bollier, and Kahn [1983] and Agmon [1985].
} 
events. In the case of transfer risk, for example, elements of chance such as variations in world interest rates and terms of trade directly affect a country's ability to pay. However, whether it meets its obligations also depends on elements of choice, such as the macro-economic policies it adopts in the face of these events, which reflect its willingness to pay. Similarly, commercial risks include elements under managerial control ranging from possible errors in project selection/design or in the management of ongoing operations to diversion of the firm's profits and assets by local owners, managers, pr workers including but not limited to fraud. ${ }^{3}$ However, these commercial risks also include the exposure of these firms or projects to general policy measures the host country may adopt in managing its economy or to specific policy measures in reaction to a firm's success or failure. Examples of the former are the austerity measures adopted by developing countries in response to their debt crises, which have thrown many local firms into severe financial crises of their own. An example of the latter in reaction to firms' success is the imposition of a windfall profits tax on oil production when prices are high or other measures with a similar effect such as the regulation of wellhead or export prices or the renegotiation of extraction contracts. In the case of troubled firms, the risk is that the firm may not be bailed out directly or indirectly, a risk of omission rather than of commission.

The interaction between chance and choice at the country level in the risk of with drawing contracts with LDCs is illustrated in Table 3. Certain risks, such as swings in world economic activity or variations in world interest rates are pure risks (exogenous risks) as far as the LDC is concerned insofar as they have little or no influence over such events, very much like natural catastrophes. Other risks, ranging from the possibility of shifts in commercial and competitive policies to the potential for a violent revolution resulting in the abrogation of international obligations, are largely or entirely the result of internal political forces (endogenous risks), although they may respond to some extent to external situations. Most risks, though, fall in the category of interactive risks in that they are joint result of external circumstances and the country's policy response to those circumstances.

Obviously, the dividing line between chance and choice at the policy level is extremely fuzzy, as is the line between what constitutes a project or company-specific commercial risk and what constitutes an element of transfer or political risk. This lack of specificity is a major barrier to writing enforceable contracts across borders. It undoubtedly explains much of the skewing of the structure of external financing for LDCs discussed in Section 3. However, it also plays a key role in determining the comparative advantage of different parties in managing international risks since risk mitigation, in this case the ability to deter opportunistic behavior at the country or firm level, will be of paramount importance.

The purpose of the foregoing is to relate the dimensions of risk affecting international contracts to the sources of comparative advantage in different risk management functions in

\footnotetext{
${ }^{3}$ This dimension of shareholder control over managers as well as conflicts between lenders and investors is now emerging as a leading topic of study in finance. For a excellent summary see Barnea, Haugen, and Senbet [1985].
} 
Table 3: Dimensions of international trade risks

\begin{tabular}{|c|c|c|c|}
\hline \multirow[b]{2}{*}{$\begin{array}{l}\text { Nature of } \\
\text { exogenous } \\
\text { risk factors }\end{array}$} & \multicolumn{3}{|c|}{ Nature of endogenous risk factors ${ }^{4}$} \\
\hline & Not significant & Specific & General \\
\hline $\begin{array}{l}\text { Not } \\
\text { significant }\end{array}$ & no risk & $\begin{array}{l}\text { Micropolitical } \\
\text { targeted } \\
\text { expropriation, } \\
\text { shift in } \\
\text { regulation }\end{array}$ & $\begin{array}{l}\text { Macropol. } \\
\text { blanket } \\
\text { exprop., } \\
\text { breakdown } \\
\text { in public } \\
\text { order }\end{array}$ \\
\hline $\begin{array}{l}\text { Affecting } \\
\text { particular } \\
\text { sectors }\end{array}$ & $\begin{array}{l}\text { Microeconomic } \\
\text { firm specific } \\
\text { commercial } \\
\text { losses }\end{array}$ & $\begin{array}{l}\text { Microinteractive } \\
\text { windfall } \\
\text { taxes }\end{array}$ & $\begin{array}{l}\text { more of } \\
\text { same }\end{array}$ \\
\hline $\begin{array}{l}\text { Affecting } \\
\text { general } \\
\text { economy }\end{array}$ & $\begin{array}{l}\text { Macroeconomic } \\
\text { commercial } \\
\text { losses }\end{array}$ & $\begin{array}{l}\text { Macrointeractive } \\
\text { commercial } \\
\text { losses, } \\
\text { transfer } \\
\text { losses }\end{array}$ & $\begin{array}{l}\text { total } \\
\text { loss }\end{array}$ \\
\hline
\end{tabular}

order to judge the comparative advantage of different classes of institutions in managing international trade risks. The result is presented in Table 4.

For simplicity three functions are focused upon: a combination of risk identification and analysis of incidence, risk mitigation, and risk allocation. While admittedly subjective, this table suggests that exploiting comparative advantage requires an unbundling of macro and micro risks as well as some specialization by institution in terms of the functions they perform.

Official lenders such as the World Bank, for example, have an advantage in the assessment and mitigation of endogenous macro level risks given their access to policymakers, the sanctions they can exert if their suggestions are not followed, and the seniority of their claims in case of rescheduling. However, their capacity and willigness to take on various of the

\footnotetext{
${ }^{4}$ e.g. Public order - wars, coups violence; Policy shifts - change of party, change of government, change of minister, change of priorities; Macroeconomic policy - level of public expenditure, real exchange rates, exchange controls, credit conditions, commercial policy, labor market policy, etc. Management - efficiency, honesty.

${ }^{5}$ e.g. Trade - protectionism, reduced global demand, shifting terms of trade. Financial - increased interest rates, loss of access to markets or institutions.
} 
exogenous risks inherent in LDC economic undertakings are quite limited. Typically they lend only on a general obligation basis and thus, by definition, do not bear specific risks such as shifts in commodity prices or the commercial failures of sectoral programs or specific projects. Further, because of their senior creditor status, they are able to shift many of the remaining risks to less senior claimants. At the micro level, they have substantial advantages in mitigating risks associated with the selection and execution of standard types of projects. However, they lack the commercial knowledge and profit incentives necessary to monitor more enterprenurial activities.

Export credit agencies have many of the same leverage benefits with regard to the macro risks of borrowing countries. Their exposure situation, however, is often worse, since given their relatively inflexible pricing and selection procedures they often are the victims of adverse selection. The same is true at the micro level.

Commercial banks, because of their demonstrated ability to act collectively, also have strong leverage at the macro level. However, the current spotlight on their precarious capital positions makes it painfully clear that they are overexposed to such risks. At the micro level,

Table 4: Comparative advantage in international risk management

$\begin{array}{lllllll}\text { Institution } & \begin{array}{l}\text { Official } \\ \text { lenders }\end{array} & \begin{array}{l}\text { Export } \\ \text { credit }\end{array} & \begin{array}{l}\text { Comm. } \\ \text { banks }\end{array} & \begin{array}{l}\text { Instit. } \\ \text { investors }\end{array} & \begin{array}{l}\text { Direct } \\ \text { invest. }\end{array} & \begin{array}{l}\text { Local } \\ \text { invest. }\end{array}\end{array}$

Risk management function

$\begin{array}{ll}\text { Macro risks } & \\ \text {-assessment } & ++ \\ \text {-mitigation } & ++ \\ \text {-divers. } & 0\end{array}$

Micro risks

-assessment

-mitigation

-divers.

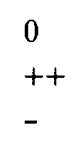

$-$

$\begin{array}{ll}+ & - \\ + \text { to }-7 & -\end{array}$

$+\quad+$

$\begin{array}{ll}++ & 0 \\ ++ & 0 \\ +- & +\end{array}$

$0 \quad 0$

0

$+$

0 to $+^{6}$

$+\quad--$

$0+$

$\begin{array}{ll}0 & + \\ - & - \\ 0 & -\end{array}$

$++\quad++$

$++\quad++$

$0^{8} \quad-$

$6++$ if allowed to have significant local operations.

${ }^{7}$ MDBs appear to have an advantage in influencing micro-level policy choices such as output pricing or limiting diversion of funds in capital goods purchasing. However, they appear to be at a disadvantage in monitoring management performance and limiting the diversion of proceeds in commercial ventures. The International Finance Corporation, for example, a significant lender and investor in third world enterprises, finds that it shares joint ownership of many "poor projects" with local owners who are doing extremely well.

${ }^{8}$ Depends on whether micro risk is country or project specific or if it is specific to the industry on a worldwide basis. 
they may be advantaged or disadvantaged depending on whether they operate extensively within the local economy and are allowed to bring full sanctions to bear on local borrowers in the case of nonperformance.

Institutional investors, including insurance companies and pension funds, have little or no leverage over macro or micro risks, but could diversify various LDC risks to a much greater extent than the much more highly exposed banks and credit agencies. Direct investors clearly have greater expertise in managing micro level risks, but typically are at a disadvantage in terms of mitigation macro-level risks.

Local investors presumably have information advantages at the micro level, but they may or may not have advantages in terms of mitigating particular risks of the incidence of those risks. With regard to risk of loss resulting from changes in government policy, locals could conceivably have more or less leverage than foreign governments, banks, or firms. In those cases where foreign borrowing is accompanied by capital flight, though, it would appear that foreign entities have rhe upper hand. Local investors may also differ in the impact of particular measures, particularly those associate with foreign exchange transfer. Since they value local expenditures more highly than do foreign investors, they have an option to switch their expenditures to the local market that foreigners do not.

\section{What's wrong with the current structure of international financing for $\mathrm{LDCs}^{9}$}

The single most striking feature of the mix of international financing for LDCs is the increasingly dominant role played by general obligation borrowing, mostly in the form of floating rate commercial bank loans. This can be seen clearly in Figure 1 which compares the level and breakdown of LDC financing in various years from 1960 to 1963 , together with a "best guess" and an "improved" forecast for 1987.

While borrowing from banks on a general obligation basis has some clear advantages, it also has several drawbacks and several characteristics that may either be beneficial or detrimental depending on the circumstances. Its primary advantages are its apparent low cost and its after-the-fact flexibility. Its clear disadvantages are its lack of risk shifting - the obligations are not contingent on any aspect of performance of the local economy - and its poor hedge characterisitics - LIBOR-linked debt service varies perversely with most LDCs' ability to pay.

Two key characteristics that can be viewed are the nonspecific nature of bank lending and its concentration in few, relatively homogeneous lending institutions. The fact that it typically entails general obligations is a positive feature in that it has allowed borrowing countries to maintain complete control over the use of borrowed funds. But it is a negative feature in that this does not involve foreign lenders or investors taking a stake in projects or enterprises - and hence it contributes little or nothing to the mitigation of micro-level risks. Further, until a country finds itself in sufficient difficulty that it must accept an IMF policy package, it provides lenders with little leverage over macro-level risks. It is ironic that in LDCs ministers of finance shoulder much more of the burden of capital allocation and operational control of micro-level economic activity than in more developed societies.

\footnotetext{
${ }^{9}$ See Lessard and Willimson [1985] for much more extensive discussion of the shortcomings of the current structure of international financing for LDCs.
} 
Figure 1: Composition of net capital flows to developing countries, 1960, 1970, 1980, 1983, and projections for 1987.

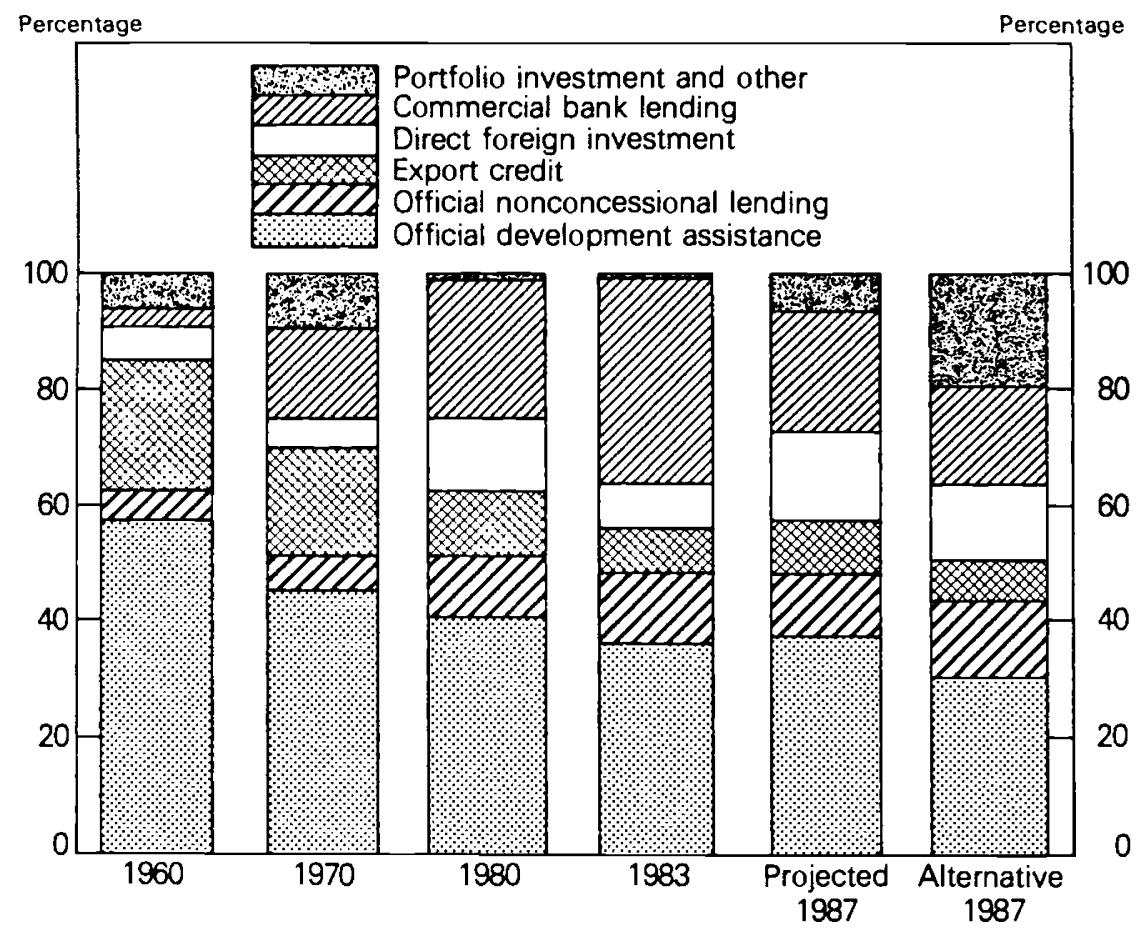

Source: OECD, Development Co-operation, 1984, and estimates in Lessard and Williamson (1985).

\section{What is needed}

While the existing structure is inefficient along many dimensions, there are a few key areas where a great deal of improvement is possible. These are listed in Table 5.

\section{How export credit agencies can contribute}

Many of the innovations outlined above involve transferring micro-level (commercial) risks to foreign investors, lenders, or providers of services. Typically, this involvement will be by parties with a comparative advantage in managing such risks by virtue of their knowledge of specific industries, their ability to manage specific activities, and/or their relative ability to diversify away certain key risk elements.

However, these same parties - direct foreign investors, firms with alternative commercial linkages to specific projects such as licensing or other sales or services contracts involving contingent compensation, and institutional suppliers of risks capital - typically are at a 


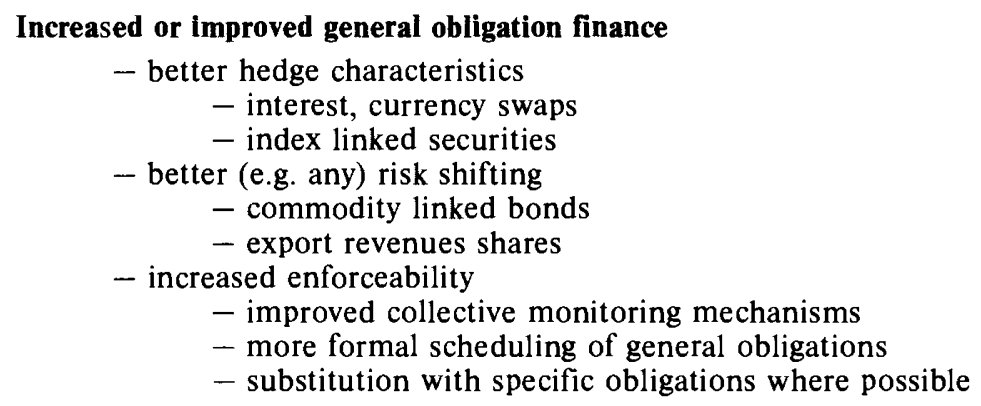

Increased stand alone finance

- improved protection from transfer risk

- escrowing of export proceeds

- scheduling on par with general obligations

- insurance of transfer, noncommercial risks

- incentives for stand alone as opposed to general obligations

\section{Increased risk capital}

- improved climate for portfolio investment

- improved climate, insurance for direct investment

- extension of scheduling, insurance to quasi-equity contracts as well as credits

disadvantage in coping with macro-level noncommercial risks. Export credit agencies are natural parties to unbundle these two types of risks. They could, for example, simultaneously insure some of these macro risks and "take a place at the table" to exert leverage on behalf of these claims. They also could exert leverage within the international financial community, especially the World Bank (and the other MDBs) and the IMF, to accord at least equal treatment to project specific claims whether these were outright credits or contracts contingent on some measure of project success. All of these steps would have the additional advantage of helping to create the conditions necessary for a viable private market in pure country risks. ${ }^{10}$

In addition to taking on more of the macro (noncommercial) risks faced by other parties, export credit agencies could also reduce their own exposures to adverse selection by exporters of capital goods or services by requiring (or encouraging through more favorable rates) that contracts be written in such a way as to transfer identifiable commercial risks to these firms. Such steps would go a long way to reintroducing appropriate micro-level risk management while maintaining or improving the management of macro-level risks.

\footnotetext{
${ }^{10}$ The term pure country risks refers to losses on scheduled general obligations. These would serve as a proxy for the transfer risk elements inherent in more penetrating contracts.
} 


\section{BIBLIOGRAPHY}

ALIBER, Robert [1973]: "The interest rate parity theorem: A reinterpretation", Journal of Political Economy, 81, No. 6.

ALIBER, Robert [1978]: "The integration of national financial markets", Weltwirtschaftliches Archiv.

AGMON, Tamir [1973]: "Country risk: The significance of the country factor for share price movements in the U.K., Germany, and Japan", Journal of Business, January.

AGMON, Tamir [1985] : Political Economy and Risk in World Financial Markets, Lexington, Ma: Lexington Books.

AGMON, Tamir and DIETRICH Kim [1983]: "International lending and income redistribution: An alternative view of country risk", Journal of Banking and Finance, December.

BARNEA, Amir, HAUGEN, Robert and SENBET Lemma [1985]: Agency Problems and Financial Contracting, Englewood Cliffs, N.J.: Prentice-Hall.

BLITZER, Charles, LESSARD, Donald and PADDOCK James [1984]: "Risk bearing and the choice of contract forms for oil exploration and development", The Energy Journal, V, No. 1.

DOOLEY, Michael and ISARD, Peter [1980]: "Capital controls, political risk, and deviations from interest rate parity”, Journal of Political Economy, 88, No. 2.

EATON, Jonathan and GERSOVITZ Mark [1981]: "Debt with potential repudiation: Theoretical and empirical analysis", Review of Economic Studies, 46.

EATON, Jonathan [1983]: "Country risk: An economic perspective", in Herring op. cit.

GHADAR, Fariborz, KOBRIN, Stephen and MORAN Theodore [1985]: Managing International Political Risk: Strategies and Techniques, Washington, D.C.: Landegger Program in International Business Diplomacy, Georgetown University.

HERRING, Richard [1983]: Managing International Risk, Cambridge: Cambridge University Press.

KOBRIN, Stephen [1982]: Managing Political Risk Assessment: Strategic Response to Environmental Change, Berkeley: The University of California Press.

KUNREUTHER, Howard and KLEINDORFER, Paul: "Insuring against country risks: Descriptive and prescriptive aspects", in Herring, op. cit.

LESSARD, Donald [1976]: "World, country, and industry relationships in equity returns: Implications for risk reduction through international diversification", Financial Analysts Journal, JanuaryFebruary.

LESSARD, Donald [1983]: "North-South financing: implications for multinational banking", Journal of Banking and Finance, December.

LESSARD, Donald and WILLIAMSON [1985]: Financial Intermediation Beyond the Debt Crisis, Washington, D.C.: Institute for ternational Economics.

RADCLIFFE, Julian [1983]: "The principles of managing political risk and the use of insurance", in Ghadar, Kobrin, and Moran, op. cit.

SOLNIK, Bruno [1973]: European Equity Markets, Lexington, Ma: Lexington Books.

VERNON, Raymond [1985]: "Organizational and institutional response to international risk", in Herring, op. cit.

WALTER, Ingo [1981]: "Country risk, portfolio decisions, and regulation in international bank lending", Journal of Banking and Finance, March.

WORLD BANK [1985]: World Development Report. 